\title{
New species of dung beetles (Coleoptera: Scarabaeidae: Scara- baeinae) from Costa Rica and Panama
}

\author{
ÁNGEL SOLÍS ${ }^{1} \&$ BERT KOHLMANN ${ }^{2}$ \\ ${ }^{1}$ INBio, Apdo.22-3100, Santo Domingo de Heredia, Costa Rica asolis@inbio.ac.cr \\ ${ }^{2}$ Universidad EARTH, Apdo. 4442-1000, San José, Costa Rica bkohlman@earth.ac.cr
}

\begin{abstract}
The following new species of dung beetles (Coleoptera: Scarabaeidae) from Costa Rica and Panama are described: Copris tridentatus sp. nov., Onthophagus notiodes sp. nov., Onthophagus xiphias sp. nov. and Trichillum arcus sp. nov. Pedaridium bradyporum (Boucomont) is reported from the Pacific slope of Costa Rica for the first time. Drawings of the dorsal habitus of all species are provided.
\end{abstract}

Key words: Coleoptera, Scarabaeidae, Copris, Onthophagus, Pedaridium, Trichillum, new species, Costa Rica, Panama

\section{Introduction}

During the last twelve years the National Biodiversity Institute (INBio) in Costa Rica has conducted an extensive nationwide insect survey. Material from this survey, as well as the collections of H.F. Howden collection (Ottawa) and the University of Nebraska State Museum (Lincoln), has yielded four new dung beetle species belonging to the genera Copris Geoffroy, Onthophagus Latreille and Trichillum Harold. Pedaridium bradyporum (Boucomont) is reported for the first time from the Pacific slope of Costa Rica.

Measurements were made to the nearest $0.1 \mathrm{~mm}$ using an ocular micrometer. Holotypes and allotypes are deposited in the INBio collection in Santo Domingo de Heredia $(C$. tridentatus sp. nov., O. notiodes sp. nov. and T. arcus sp. nov.) and the Canadian Museum of Nature, Ottawa (O. xiphias sp. nov.). Paratypes are deposited in the INBio collection (all species), the Canadian Museum of Nature in Ottawa (O. notiodes sp. nov., O. xiphias sp. nov. and T. arcus sp. nov.), University of Nebraska State Museum and Andrew Smith's collection in Lincoln, Nebraska (O. xiphias sp. nov.) and Vaz-de-Mello's collection in Lavras, Brasil (T. arcus sp. nov.). 
Diagnosis. This species is distinguished from other Copris species by the following combination of characters: head with a tridentate clypeus; head and thorax are unarmed, the head having only a small gibbosity; head and pronotum covered by large, flat and shallow umbilicate punctures.

Description. Holotype. Male: Length $13.2 \mathrm{~mm}$. Humeral width $7.1 \mathrm{~mm}$. Body oblong and convex, completely black.

Head unarmed; clypeus tridentate, teeth not prominent; clypeus with faint simple punctation; genae and base of head with coarse umbilical punctation; frons with a smooth gibbosity; eyes small, maximum ocular width about two thirds of ocular length; genal suture slightly arched; posterior angles of head subquadrate.

Pronotum unarmed; anterior angles acute, the margin behind them sinuate; lateral carina acute; coarse umbilicate punctures all around pronotal margin, and on anterior angles, lateral fossae, median longitudinal sulcus and to both sides of the pronotal disc; median longitudinal sulcus deeply impressed.

Elytra with eighth and tenth striae complete, ninth stria arising at about one third of elytron; striae crenate-punctate, separated by 1-2 $\mathrm{x}$ their widths on disc; intervals convex, sparsely minutely punctate.

Pygidium coarsely and uniformly punctate, margin complete.

Protibial spurs curved slightly inward and tapering to an acute point, pro- meso- and metafemora covered ventrally with coarse umbilicate punctures, as well as a great part of the lower surfaces with the exception of the disc of the metasternum

Female. - Unknown.

Variation. Length $12.5-13.2 \mathrm{~mm}$. Humeral width $6.5-7.1 \mathrm{~mm}$. Frons gibbosity can also be umbilico-punctate.

Examined material (2 specimens). Holotype, male: COSTA RICA. San José: Ciudad Colón, El Rodeo, 1000 m, 17 Oct 1988, Col.: A. Solís. Paratype. ibid., 1 specimen.

Habitat. The specimens were collected using traps baited with human excrement inside a tropical seasonal dry forest.

Geographical distribution. This species is only known so far from the "El Rodeo" Forest Reseve, near San José, at the base of the Escazú heights.

Chorological affinities. The distribution of this new species is embedded within the distribution of its closest relative, C. costaricensis Gahan, found from Chiapas to Panama.

Taxonomic relationships. Copris tridentatus is in the remotus complex as defined by Matthews (1961), and is keyed there to Copris costaricencis. It is easily separated from this species by the presence of a tridentate clypeus, anterior pronotal margin without a central tooth, a complete pygidial margin and the lack of a male horn. In general the species has characters intermediate between $C$. costaricensis and $C$. sallei, although the pronotal punctation has basically the same pattern as in $C$. costaricensis.

Etymology. The name refers to the clypeus having three teeth. 
Diagnosis. This species is distinguished by the following combination of characters: pronotal surface without setae; body colour uniform, reddish-brown with cupreous red or green metallic reflections, meso-and metafemora not yellow in their central part; setae of the apex of the metatibia always thick, forming a comb, stiff, always the same size and with fine setae alternating within them and with a size never exceeding 2.5 times the size of the stiff setae; elytra surface much sharpened and punctate; males have small teeth at the base of the head; short, broad, massive clypeal horn; a very square angle exists between the clypeal tooth and the gena; pronotal male process with lamellae that point slightly inwards and upwards.

Description. Holotype. Male: Length: $7.8 \mathrm{~mm}$. Humeral width: $4.1 \mathrm{~mm}$. Head and pronotum cupreous red with intense golden-green reflections, elytra burgundy colours, rest of the body a dark reddish-brown with greenish cast.

The head has a clypeal horn, thick set at its base and broadening toward the apex. The frontal area rugosely punctate, eyes small. There is a pair of small horns, teeth like, between the eyes and toward the base of the head. The angle between the clypeal tooth and the gena is $90^{\circ}$.

Pronotum slightly shagreened and uniformly punctate, prominences broadly bladelike, slightly pointing upwards, parallel and slightly converging at the apex.

Elytra with eight striae evident, each with large punctures, intervals flat and covered with fine punctation, surface shagreened.

Pygidium shagreened and covered with regular punctation, carina running through the middle.

Protibiae long and slender, with tarsi present and four external teeth. Meso- and metatibia dilated toward the apex. First metatarsus very long and almost rectangular in shape.

Allotype. Female: Length $6.9 \mathrm{~mm}$. Humeral width: $3.9 \mathrm{~mm}$. Similar to male but unarmed, with a transversal carina at the middle of the head and the anterior border of the clypeus shows two well developed teeth separated by an open "v" notch, there are also two pointed small teeth, at the base of the head between the eyes. Pronotal process formed by two small blunt teeth. Foretibia short and broad.

Variation. Length: $6.1-7.8 \mathrm{~mm}$. Humeral width: 3.2-4.9mm. Specimen body colour can vary from an intense cupreous red to cupreous green. Males vary from having a well developed clypeal horn to just a small lamella; head horn and pronotal projections also vary from well to feebly developed. Less developed males lack the strongly developed angle between the clypeal teeth and the gena. Pygidium can go from a fine to a strong punctation.

Examined material (22 specimens). Holotype, male: COSTA RICA. Grano de Oro, 1120 m, Chirripó, Turrialba, Prov. Cartago, Feb, 1993, P. Campos. Allotype, female: ibidem, Mar., 1993. Paratypes. Cartago: Grano de Oro, 1120 m, Chirripó, Turrialba, Marzo 

Octubre 1992, 1 specimen; Febrero 1993, 1 specimen. Heredia: Estación 1070 m, transecto altitudinal Finca la Selva a Volcán Barva, Parque Nacional Braulio Carrillo, trampa de foso, 17 abril 2001, D. Brenes, 2 specimens, 18 abril 2001, 2 specimens.

Habitat. O. notiodes was collected in cloud forest at elevations ranging from 1070 to $1120 \mathrm{~m}$.

Geographical distribution. This species is known so far from Grano de Oro, in the province of Cartago and along the Atlantic slope of Barva volcano.

Chorological affinities. The new species occupies higher terrain on the Caribbean slope, whereas $O$. praecellens is found at lower altitudes on both slopes.

Taxonomic relationships. O. notiodes keys to O. praecellens in Kohlmann and Solís (2001). The males are easily distinguished by their short, broad, massive and not strongly backwardly curved clypeal horn, whereas $O$. praecellens has a finer, slender and backwardly curved clypeal horn. The new species has a sharp angle between the clypeal tooth and the gena, whereas $O$. praecellens has a rather open angle. $O$. notiodes has the pronotal process with lamellae that point slightly inwards and upwards, while those of $O$. praecellens are parallel and level. In females the clypeal teeth are well developed, but the head horns are smaller than in $O$. praecellens. Elytra are much more shagreened in $O$. notiodes than in $O$. praecellens.

With the exception of elytral shagreenation, there are no characters separating the females of both species.

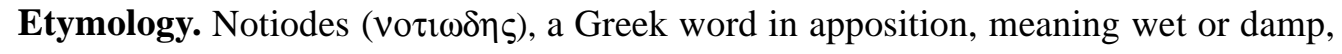
making reference to the very humid tropical forests, where this species lives.

\section{Onthophagus xiphias Solís \& Kohlmann, sp. nov. (Figs. 3-4)}

\section{Onthophagus quetzalis Howden \& Gill, 1993 (in part): 1101.}

Diagnosis. This species is distinguished by the following combination of characters: pronotal surface without setae; body colour uniformly reddish-brown; meso-and metafemora yellow in their central part; profemur brown; elytral surface with setae; functional wings; clypeal horn long with a thin base and forked distally; pronotal horn long, grooved dorsally and ventrally, ending in a thin rounded tip.

Description. Holotype. Male: Length $6.1 \mathrm{~mm}$. Humeral width: $3.7 \mathrm{~mm}$. Body coloration is reddish-brown, more so in the pronotum, the meso- and metafemora are yellowish.

The head presents a clypeal horn, slender at its base but broadening and forking toward the apex. The frontal area of the head is smooth, with punctures toward the base; eyes small. 


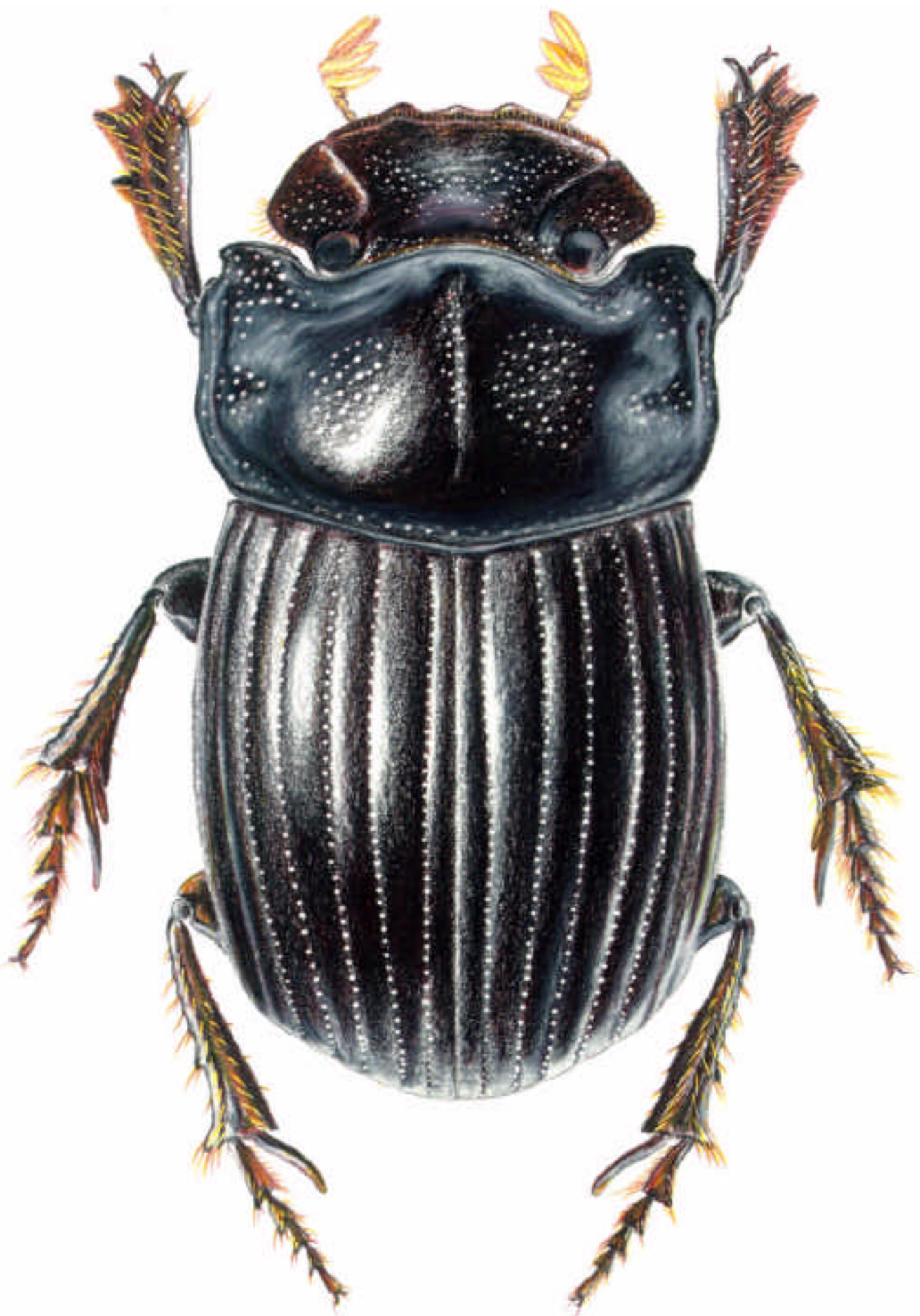

FIGURE 1. Dorsal habitus of Copris tridentatus Solís \& Kohlmann, sp. nov. (holotype). 


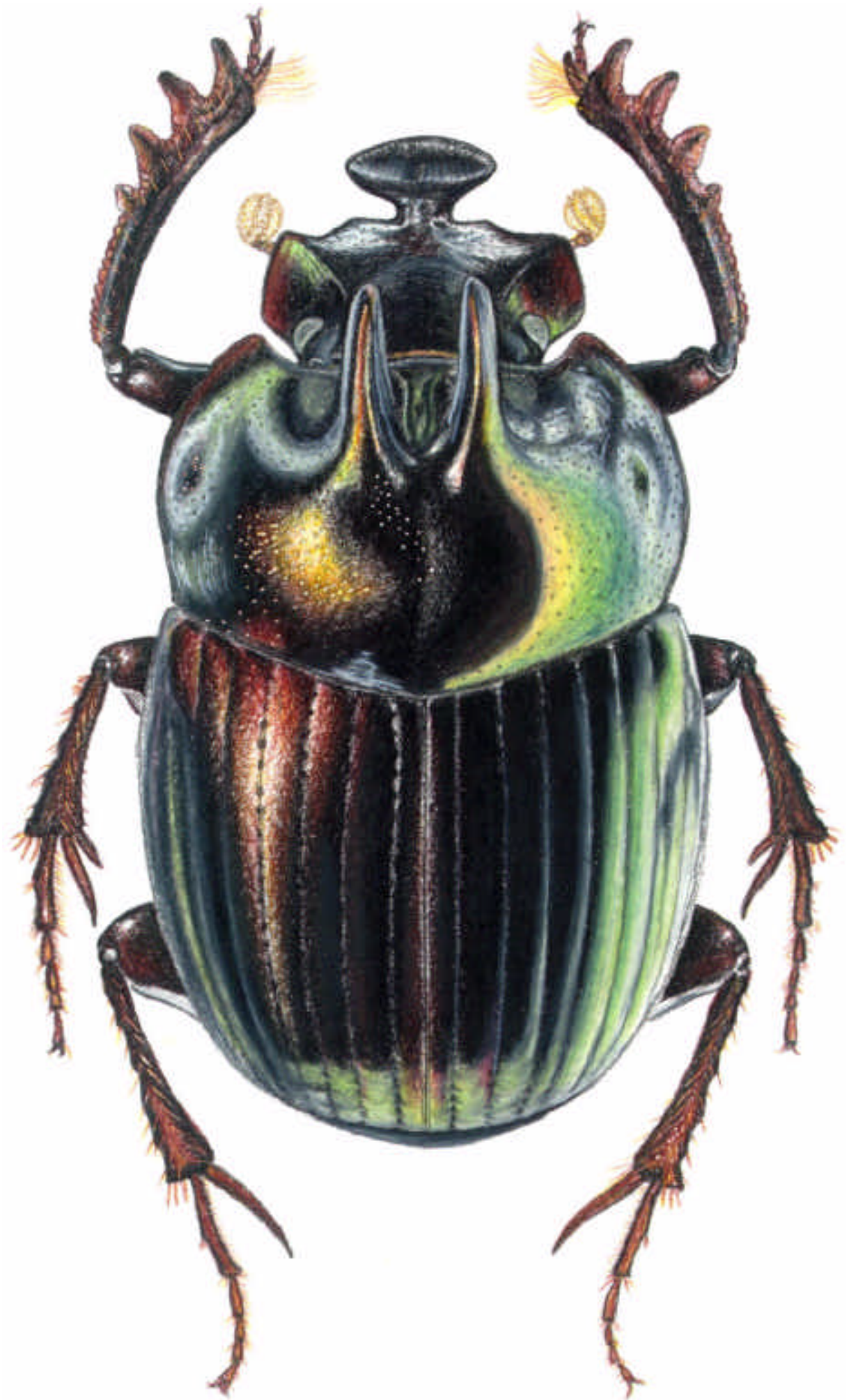

FIGURE 2. Dorsal habitus of Onthophagus notiodes Solís \& Kohlmann, sp. nov. (holotype). 


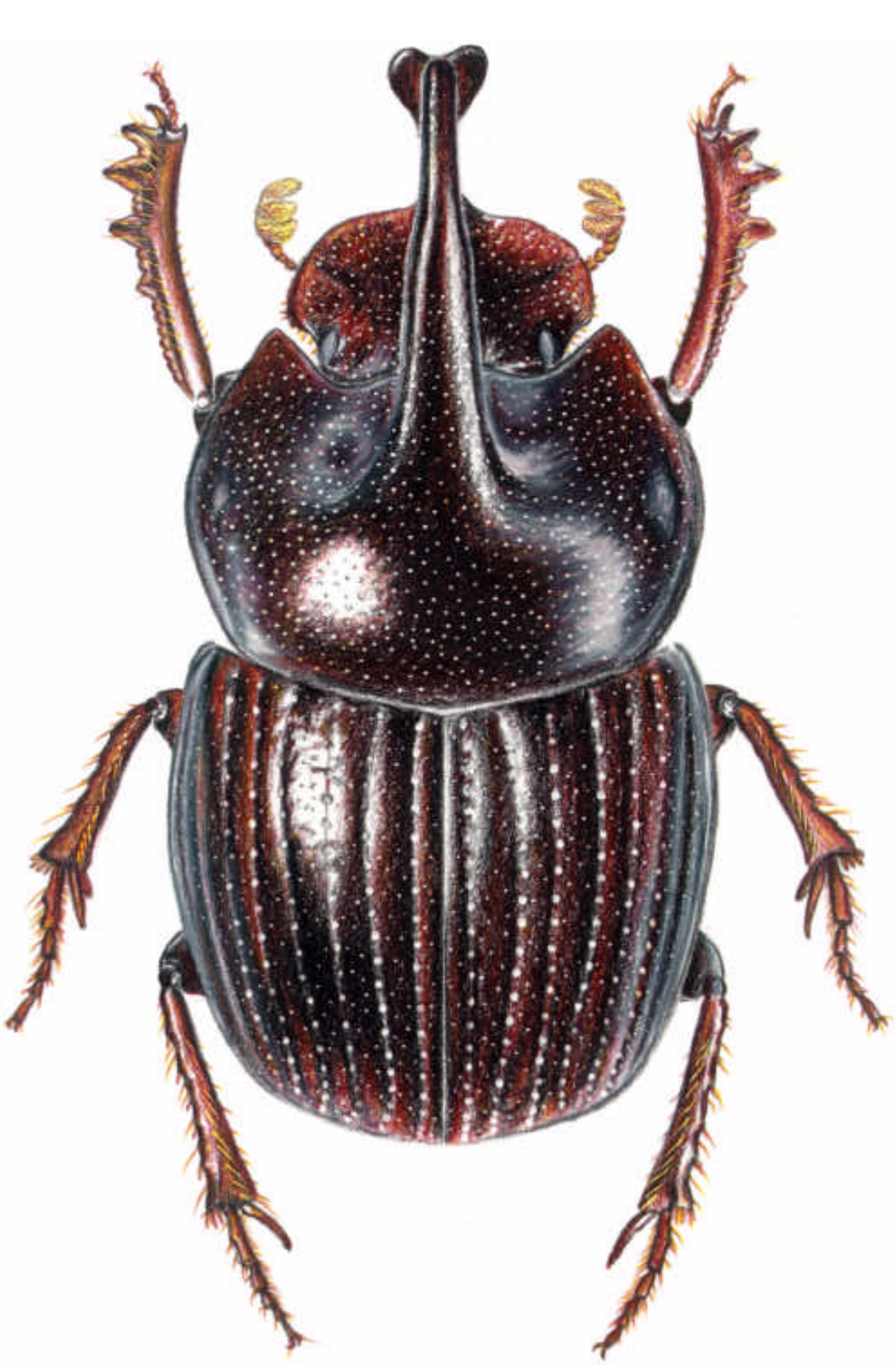

ZOOTAXA

FIGURE 3. Dorsal habitus of Onthophagus xiphias Solís \& Kohlmann, sp. nov. (holotype). 


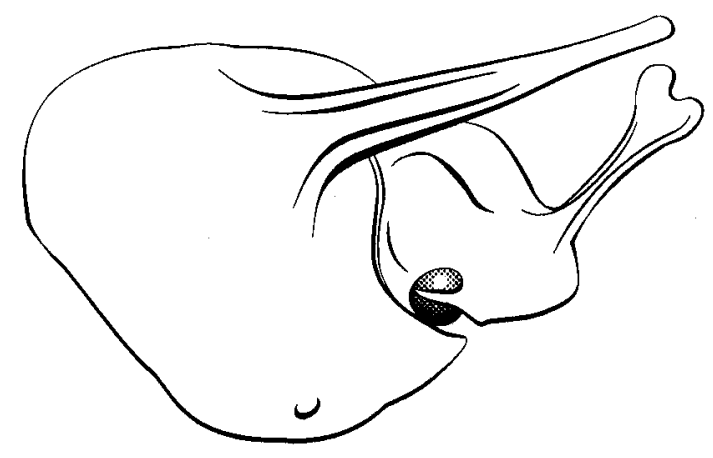

FIGURE 4. Fronto-lateral view of Onthophagus xiphias Solís \& Kohlmann, sp. nov. (holotype).

The pronotum has a long and slender horn grooved dorsally and ventrally at its base and ends in a rounded tip. Pronotal surface slightly shagreened and covered with umbilicate punctures.

Elytra with eight distinct striae, each with umbilicate punctation, intervals broad and slightly convex, with regular and coarse punctation. Elytral apices and epipleural stria with short and erect setae.

Pygidium slightly shagreened, with umbilical punctures bearing short, stiff and erect setae.

Protibiae long and slender, with tarsi present and four external teeth. Meso- and metatibiae dilated toward the apex. First metatarsus long and almost rectangular in shape.

Allotype. Female: Length $5.8 \mathrm{~mm}$. Humeral width: $3.6 \mathrm{~mm}$. Similar to male but unarmed, with a transversal carina at the middle of the head and the anterior border of the clypeus shows two well developed teeth separated by a "v" notch. Protibiae broader and shorter than the male.

Variation. Length 5.2-6.6 mm. Humeral width: 2.9-3.8 $\mathrm{mm}$. Sometimes the mesoand metafemora are not yellow, but brown in their central parts.

Examined material (101 specimens). Holotype, male: PANAMA. Chiriquí, Prov. Hornito, Finca la Suiza, 1220 m, 31.V.2000. H. \& A. Howden, FIT. Allotype, female: ibid, 2.VI.2000. Paratypes. PANAMA. Chiriquí, Hornito, Finca La Suiza, 1220 m, H. \& A. Howden, FIT, 1 specimen, 28.V.2000, 3 specimens, 29.V.2000, 7 specimens, 8 specimens, 30.V.2000, 31.V.2000, 10 specimens, 1.VI.2000, 4 specimens, 2.VI.2000, 9 specimens, 3.VI.2000, 7 specimens, 4.VI.2000, 11 specimens, 5.VI.2000, 8 specimens, 6.VI.2000, 18 specimens; Finca La Suiza, $20 \mathrm{~km}$ N Gualaca, $1350 \mathrm{~m}, 10-13 . V I .1995$, J. Ashe \& R. Brooks, FIT, 1 specimen, 22-24.V.1995, J.S. \& A.K. Ashe, 1 specimen, 1350 m, 1013.VI.1995. J. Ashe \& R. Brooks, ex: f.i.t.(196). 1 specimen; 2 km NW Hornitos, N $8^{\circ} 39.5^{\prime} \mathrm{W} 82^{\circ} 12.3^{\prime}, 24$. V-6.VI.2000, 1250 m, B. \& J. Gill, 7 specimens; Finca La Suiza; 5.3 km N Los Planes, N 8³9', W 82²12', V-26-30-1995, elev. 4500'. B. Ratcliffe \& M. Jameson, 5 specimens, N 8³9', W 82¹2', VII-10-13-1994, elev. 4500'. B. \& I. Ratcliffe, M. Jameson, 1 specimen; Hartmann Finca, 15 km NW H[ato el] Volcan, 1500 m, S.Peck, 25.V.1975, dung trap, 1 specimen. 
Habitat. The species was collected with flight interception and dung traps inside cloud forest at altitudes varying from $1220 \mathrm{~m}$ to $1500 \mathrm{~m}$.

Geographical distribution. The species is known so far from the Pacific slope of the Chiriquí Volcano and probably occurs in the Talamanca Range in Costa Rica.

Chorological affinities. Onthophagus xiphias, is widely separated from the known range of its closest relative, O. quetzalis, which is distributed in the Central, Tilarán and Guanacaste Cordilleras at similar altitudes (1000-1750 m) in relation to this new species. The other related species, $O$. inediapterus, is known from the Talamanca Range, but has been collected at higher altitudes (1650-1800 m) than this new species.

Taxonomic relationships. Onthophagus xiphias is postulated to be the sister species of $O$. quetzalis. This species-pair represents another geographic and phylogenetic dichotomy between the Talamanca Range and the Central, Tilarán and Guanacaste Ranges as has been already noted in Kohlmann and Solís (2001).

O. xiphias will key to O. quetzalis in Kohlmann and Solís (2001). It is easily distinguished by its much longer clypeal horn, thinner at its base and with a strongly forked distal end, whereas $O$. quetzalis has a short clypeal horn, thicker at its base and weakly forked distally. Moreover, $O$. xiphias has a very long pronotal horn, grooved dorsally and ventrally and finishing in a thin rounded tip. On the contrary $O$. quetzalis has a shorter horn, grooved only dorsally and finishing in a cannula. O. xiphias has sparse pilosity at the elytral apex; whereas $O$. quetzalis is densely pilose in this area. $O$. xiphias has a slightly shagreened pygidium with short setae; $O$. quetzalis has on the contrary a shagreened pygidium with much shorter setae. $O$ xiphias has slightly shagreened abdominal sternites and the metasternal surface is covered by simple punctation; whereas O. quetzalis has shagreened abdominal sternites and the metasternal surface is covered by umbilicate punctures.

Females of $O$. xiphias are separated from $O$. quetzalis using head characters. The first species has a more rounded head and a distinct cephalic carina, whereas the second species has a more pointed head and a weak cephalic carina.

One specimen of Onthophagus quetzalis had been reported from Hartmann Finca, Chiriquí Prov., Panama (Howden and Gill, 1993). This specimen belongs to the new species here described.

Etymology. Latinized word in apposition, taken from the Greek, xiphias ( $\left.\xi_{1} \varphi \imath \alpha \varsigma\right)$, meaning swordfish; making reference to the long and slender pronotal horn of the developed males of this species.

Pedaridium bradyporum (Boucomont, 1928) (Fig. 5)

Trichillum bradyporum Boucomont, 1928: 188.

Pedaridium bradyporum (Boucomont); Martínez, 1967: 119. 

reported for the first time from the Pacific rain forest and another new locality from the Atlantic slope. The genus has been recently revised by Ferreira \& Galileo (1993).

Examined material (6 specimens). COSTA RICA. Prov. Puntarenas, Est. Quebrada Bonita, Res. Biól. Carara, 50 m, Junio, 1991, R. Zúñiga, 1 specimen; P.N. Manuel Antonio, 80 m, VII, 1992, G. Varela, 1 specimen; Península de Osa, Estación Agujas, Sendero Homo, 300 m, 5. VIII, 2000, A. Azofeifa, 1 specimen. Prov. Limón, Est. Hitoy Cerere, Sendero a Espanel, 100-200 m, 10-20.X.2002, W. Arana, Tp. Intercepción, 1 specimen; 6-9.XII.1999, W. Arana, Tp. Luz, 1 specimen; 3.VIII.2000, W. Arana, Tp. Luz, 1 specimen

\section{Trichillum (Eutrichillum) arcus Solís \& Kohlmann, sp. nov. (Fig. 6)}

Diagnosis. This species is distinguished from other Trichillum species by the following combination of characters: metallic-colour, with head and pronotum a brilliant wine-red with green cupreous reflections, the elytra a darker wine-red with green cupreous reflections; clypeo-genal suture raised and keeled, arching and projecting towards the middle of the head, and interrupted medially.

Description. Holotype. Male: Length $3.8 \mathrm{~mm}$. Humeral width $2.7 \mathrm{~mm}$. Body short and rounded, dorsally convex. Dorsal surface brilliant wine-red on head and pronotum with green cupreous reflections; elytra darker wine red with green cupreous reflections; ventral surface reddish-brown. Dorsal surface with setae.

Head smooth, covered with umbilicate punctures that bear a golden seta; clypeus bidentate separated by a slightly rounded V-shaped notch, teeth well developed; genae projecting in an even arch; clypeo-genal suture raised and keeled, arching and projecting towards the middle of the head, but interrupted medially; eyes small and emarginated, 3.5 times longer than wide.

Pronotum smooth, covered haphazardly with umbilicate punctures of different sizes that bear a golden seta; postero-laterally with a small, black gibbosity; base not emarginated; pronotal lateral borders slightly angled anteriorly; an arched carina goes from behind and below the lateral gibbosity to the antero-lateral pronotal arch.

Elytra with eight striae, including the epipleural. Intervals slightly convex and smooth. Striae slightly impressed, more so at their apex, faintly punctate. First stria with a row of umbilicate punctures bearing an erect golden seta along its inner side. Striae 2-8 with the same row of punctures along the external side, with the exception of the second stria, which also has on its apical third the seta bearing punctures. Pygidium completely margined, smooth and convex, covered with umbilicate punctures of varying sizes and bearing an erect golden seta. 


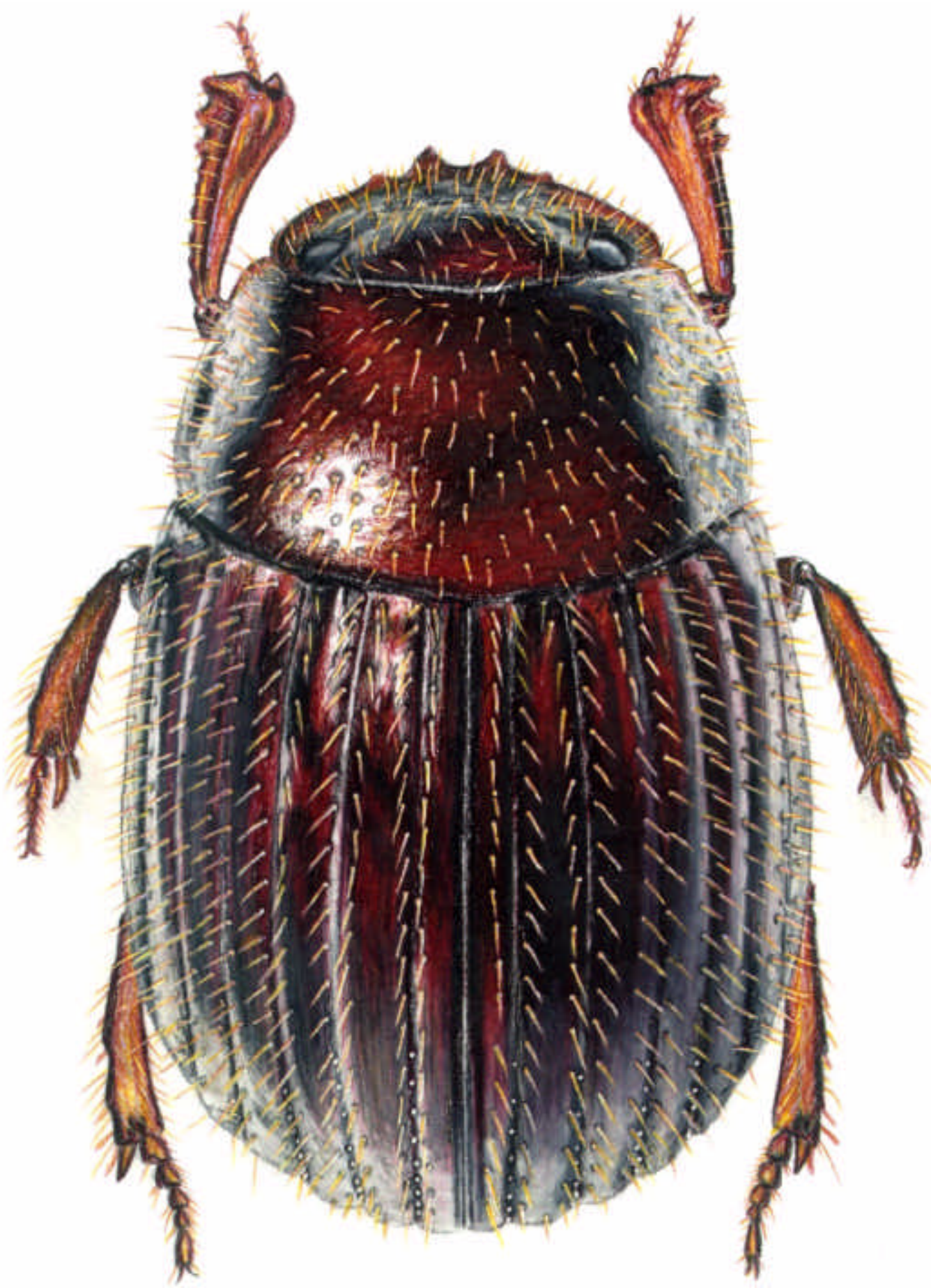

FIGURE 5. Dorsal habitus of Pedaridium bradyporum (Boucomont). 


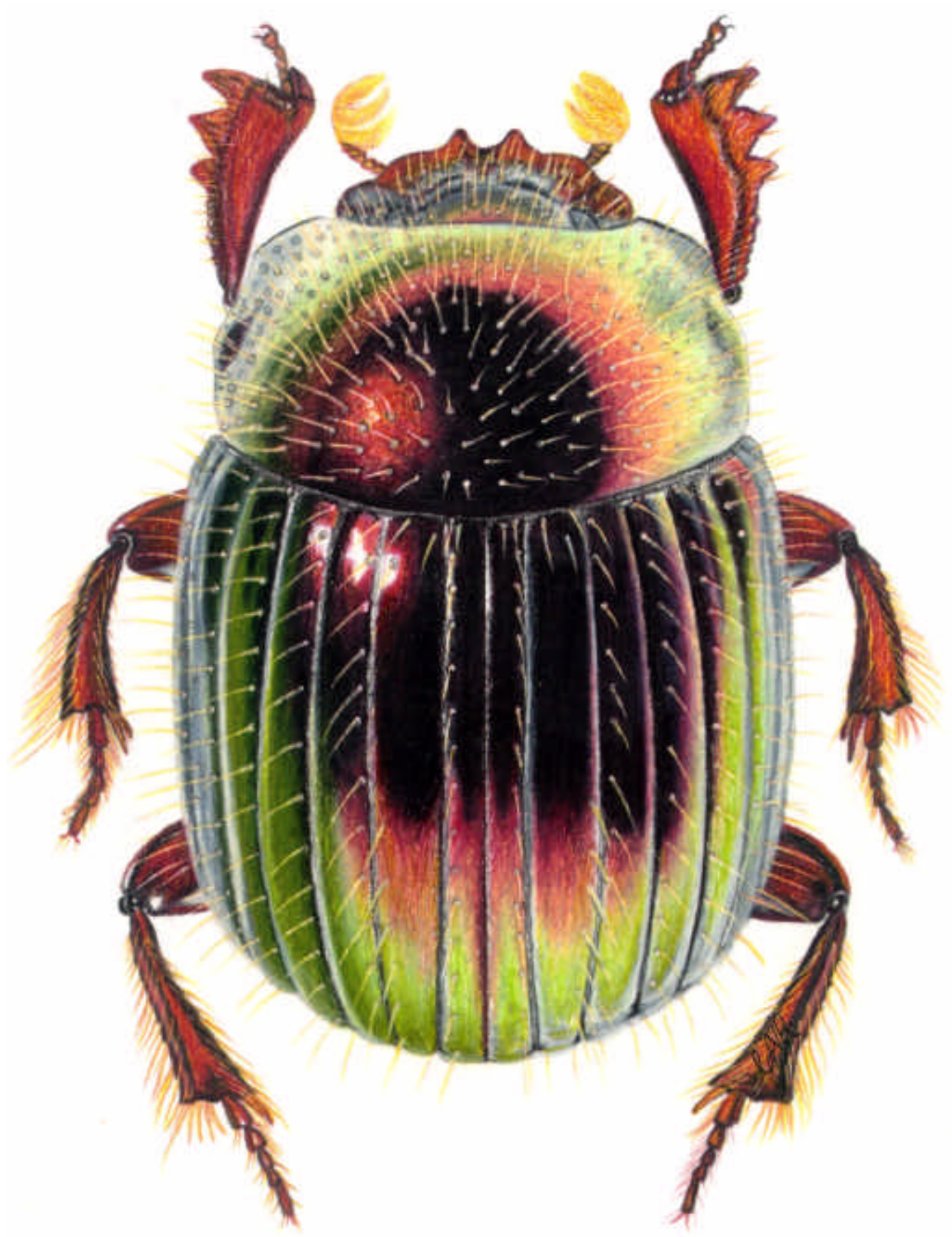

FIGURE 6. Dorsal habitus of Trichillum arcus Solís \& Kohlmann, sp. nov. (holotype). 
Femora covered by umbilicate punctures bearing an erect golden seta. Pro-, mesoepimeron, metaepisternum, pro-, meso-, metasternum and abdominal sternites covered with large, flat and shallow ocellated impressions; in the case of the metasternum the impressions lie along its margin, whereas the central area is smooth. Meso- and metafemora have a line of punctures bearing setae at the posterior ventral margin. Like all males from the subgenus Eutrichillum it has the fifth protarsus distally swollen and dorsally deeply excavated for accommodating the claws while at rest.

Allotype. Female: Length $3.5 \mathrm{~mm}$. Humeral width $2.2 \mathrm{~mm}$. Similar to male, except that the fifth protarsus is not distally swollen.

Variation. Length 2.9-4.1 mm. Humeral width 1.8-2.8 $\mathrm{mm}$. The first stria has sometimes one or two isolated umbilical punctures with an erect seta along its external margin. The second stria has a row of umbilical punctures with erect setae along its inner margin going from its apical third to its apical half. Strial punctures can become more crenulating towards the apex.

Examined material (39 specimens). Holotype, male: COSTA RICA. Est. Pitilla, 9 km S. Sta. Cecilia, P.N. Guanacaste, Prov. Guanacaste, 700m, May, 1994, C. Moraga, CRI001 832764. Allotype, female: Prov. Guanacaste, Est. Pitilla, 9 km S Santa Cecilia, 700m, Oct. 1996, C. Moraga, CRI002 500213. Paratypes. Guanacaste: ibid. allotype, 5 specimens; ibid. holotype, 1 specimen; ibid., Junio 1994, 3 specimens; ibid., Agosto 1993; Sector Santa María, 25 km NE de Liberia, 790 m, 9-27 Oct, 1996, D. Briceño, 6 specimens; 11-18 Nov, 1996, 2 specimens. Alajuela: Sector San Ramón de Dos Ríos, 1.5 Km NO Hda. Nueva Zelandia, 620m, 12-21 Julio 1996, F.A. Quesada, 14 specimens; 17-28 set 1995, 1 specimen; Puesto Quebradón, 300 m, Nov 1997, G. Rodríguez, trampas de intercepción, con agua de sal, Baykil y frutas en las tazas, 1 specimen; San Lorenzo, 600-620 m, 16-19 Septiembre 1996, F.A. Quesada, 1 specimen. Heredia: Est. Biológica La Selva, 21-VI-1998, C. Carleton \& A. Tishechkin, 1 specimen; 50-150 m, 14-Mayo 1993, INBioOET, bosque secundario, 1 specimen.

Habitat. This species has been collected using traps baited with rotting meat or with flight interception traps inside tropical rain forest.

Geographical distribution. This new species of Trichillum occurs on both the Atlantic and Pacific slopes, along the bases of the volcanoes of the Guanacaste and Tilarán Cordilleras.

Chorological affinities. So far this is the northernmost distribution range known for a member of the genus Trichillum. This species will most probably be also found in the Atlantic rain forests of Nicaragua.

Taxonomic Relationships. The species belongs to the subgenus Eutrichillum, as defined by Martínez (1967). Based on external characteristics, the clypeo-genal suture, the punctation of the pronotum and the piliferous punctation and flatness of the elytral intervals, this new species seems to be related to T. boucomonti Arrow. 
Etymology. From the Latin word meaning rainbow, a reference to the iridescent coloration of this species.

\section{Acknowledgements}

We would like to thank H.F. Howden, Ottawa and B.C. Ratcliffe, University of Nebraska State Museum, Lincoln, for providing material that led to the description of O.xiphias and to two anonymous reviewers, who greatly improved the text. We are also indebted to Claudia Aragón who did the beautiful drawings of the dorsal habitus.

\section{References}

Boucomont, A. (1928) Coprophages d'Amérique du Sud nouveaux ou peu connus. Bulletin de la Société entomologique de France, 12, 186-194.

Ferreira, A.M.R.M. \& Galileo, M.H.M. (1993) Revisão taxonômica do gênero Pedaridium Harold, 1868 (Coleoptera, Scarabaeidae, Scarabaeinae, Coprini). Iheringia, Série Zoologia, Porto Alegre, 74, 3-69.

Howden, H.F. \& Gill, B.D. (1993) Mesoamerican Onthophagus Latreille in the dicranius and mirabilis species groups (Coleoptera: Scarabaeidae). The Canadian Entomologist, 125, 1091-1114.

Kohlmann, B. \& A. Solís, A. (2001) El género Onthophagus (Coleoptera: Scarabaeidae) en Costa Rica. Giornale Italiano di Entomologia, 9, 159-261.

Martínez, A. (1967) Notas para una monografía del género Trichillum Harold, 1868. Revista de la Sociedad Mexicana de Historia Natural, 28, 119-147.

Matthews, E. (1961) A revision of the genus Copris Müller of the Western Hemisphere (Coleoptera, Scarabaeidae). Entomologica Americana, 41, 1-137. 